dlia zdorovia ditei : DSanPiN 5.5.6.12-98. [State Sanitary Regulations and Norms of the Safety of Toys and Games for the Health of Children: SSanRN 5.5.6.12-98]. URL : http://mozdocs. kiev. ua/view. php?id=4441 (in Ukrainian).

13. Derzhavni budivelni normy Ukrainy. Inzhenerne obladnannia budynkiv i sporud. Pryrodne i shtuchne osvitlennia: DBN V.2.5.-28-2006 [State Building Norms of Ukraine. Engineering Equipment of Buildings and Structures. Natural and Artificial Lighting: SBN B.2.5.-28-2006]. Kyiv : Minbud Ukrainy; 2006 : 76 p. (in Ukrainian).

14. Bokhoniuk A.I., Yanko N.V. and Platonova A.G. Sovmeshchennoe osveshcheniye uchebnykh pomeshcheniy obshcheobrazovatelnykh shkol [Combined Lighting of Educational Premises of Secondary Schools]. Kiev ; 2014 : 79 p. (in Russian).

15. Ministry of Health of Ukraine. Normy fiziolohichnykh potreb v kharchovykh rechovynakh i enerhii naselennia Ukrainy. Nakaz № 1073 vid 03.09.2017. [Norms of Physiological Needs in Nutrients and Energy of the Population of Ukraine. Order № 1073,

September 2017 URL :

https://zakon.rada.gov.ua/laws/ show/z1206-17

(in Ukrainian).

16. Khomenko I.M., Ivakhno O.P., Koziarin I.P. et al. Orhanizatsiia kharchuvannia ditei riznoho viku v osvitnikh ta ozdorovchykh zakladakh: Navchalno-metodychnyi posibnyk [The Organization of Nutrition of Children of Different Ages in Educational and HealthImproving Institutions : Manual]. Kyiv ; 2018 : 116 p.

(in Ukrainian).

17. Cabinet of Ministers of Ukraine. Pro zatverdzhennia Planu zakhodiv z realizatsii stratehii rozvytku medychnoi osvity v Ukraini na 2019-2021. : Rozporiadzhennia № 674-r vid 21.08.2019. [On the Approval of the Plan of Measures for the Implementation of the Strategy of Development of Medical Education in Ukraine for 20192021: Decree № 674-p ;

21.08.2019]. URL :

http://zakon.rada

(in Ukrainian).

Надійшла до редакції 06.03.2020

\section{CONTRAST SENSITIVITY AS A METHOD OF EARLY DETECTION OF REFRACTIVE DISORDERS IN CHILDREN OF ALL AGES}

Kharchenko L., Plyska O., Hrusha M. , Kondratok I., Shkrobanets I.

\section{КОНТРАСТНА ЧУТЛИВІСТЬ ЯК МЕТОД РАННЬОГО ВИЯВЛЕННЯ ПОРУШЕНЬ РЕФРАКЦЇ У ДІТЕЙ РІЗНОГО ВІКУ}

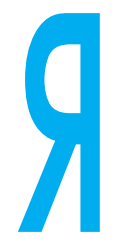

1 ХАРЧЕНКО Л.Б., 1ПЛИСКА О.І., 2ГРУША М.М., 1 КОНДРАТОК І.С. ЗШКРОБАНЕЦЬ І.Д.

1 Національний педагогічний університет ім. М.П. Драгоманова

2Національний медичний університет ім. О.О. Богомольця

ЗНАМН України к свідчать дані В003, нині у світі налічується 45 млн. сліпих людей, 3 них - 1,5 млн. дітей, 135 млн. мають серйозні порушення зору [1]. Майже щохвилини у світі через різні причини одна дитина втрачає зір. Масштабність проблеми зумовила прийняття міжнародної програми BOO3 «VISION2020: Право на зір», до якої приєдналася й Україна. Метою цієї програми є ліквідація сліпоти та слабкозорості, які
КОНТРАСТНА ЧУТЛИВІСТЬ ЯК МЕТОД РАННЬОГО ВИЯВЛЕННЯ ПОРУШЕНЬ РЕФРАКЦІЇ У ДІТЕЙ РІЗНОГО ВІКУ

1Харченко Л.Б., 1Плиска О.І., 'Груша М.М.,

1 Кондраток І.С., ЗШкробанець І.Д.

1 Національний педагогічний університет ім. М.П. Драгоманова

2Національний медичний університет ім. О.О. Богомольця

з національна академія медичних наук України

Мета дослідження : співвіднести стан рефракційно-акомодаційної системи та показників контрастної чутливості у школярів різних вікових груп. Для вирішення вказаного завдання у роботі використано схему вікової періодизації людини, що враховує анатомічні, фізіологічні і соціальні фактори.

Результати. У кожного обстеженого учня визначали гостроту зору за допомогою таблиць Головіна-Сивцева, контрастну чутливість (КЧ) - за допомогою таблиці контрастних оптотипів. $у$ результаті проведених досліджень було встановлено, що з віком спостерігається наростання частоти клінічно значущих випадків міопії і у дівчаток, і у хлопчиків. Частота ї̈ виявлення (33,74\%; n=251) у школярів, що брали участь у нашому дослідженні, майже вдвічі перевищує частоту виявлення гіперметропії (17,20\%; n=128). Загальні тенденції щодо погіршення стану контрастної чутливості загалом відповідали змінам у стані рефрактерного апарату у групах учнів жіночої та чоловічої статі та мали тотожний характер. Виявлено, що до групи учнів 3 індексом КЧ у межах 0-2 потрапляють 73,04\% від загальної кількості дівчаток та 72,00\% хлопців із різних вікових груп, в яких виявлене порушення рефракції.

Висновки. Виявлена подібність тенденцій у збільшенні частоти клінічно значущих випадків порушень стану контрастної чутливості та рефракційно-акомодаційної системи дають змогу припустити, що дослідження з використанням таблиці контрастних оптотипів можна використовувати як ранній метод доклінічної діагностики порушень рефракції у школярів.

Ключові слова: контрастна чутливість, зоровий аналізатор, міопія, гіперметропія, порушення рефракції, профілактика порушень зору у дітей.

() Харченко Л.Б., Плиска О.І., Груша М.М., Кондраток І.С., Шкробанець І.Д. СТӒТЯ, 2020.

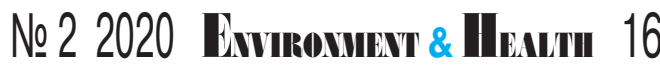




\section{CONTRAST SENSITIVITY AS A METHOD OF EARLY DETECTION OF REFRACTIVE DISORDERS IN CHILDREN OF ALL AGES \\ ${ }^{1}$ Kharchenko L., 1 Plyska O., ${ }^{2}$ Hrusha M., ${ }^{1}$ Kondratok I., 3 Shkrobanets I. \\ 1 M.P. Drahomanov National Pedagogical University, Kyiv, Ukraine \\ 20.0. Bohomolets National Medical \\ University, Kyiv \\ ${ }^{3}$ National Academy of Medical Science of Ukraine, Kyiv}

\section{Objective: We correlated the state of} refractive-accommodation system and indicators of contrast sensitivity in the students of different age groups. To solve this issue, we used the scheme of age-related periodization of a person, taking into account anatomical, physiological and social factors.

Results. In each of the participants, visual acuity was detected with the help of the GolovinSivtsev tables, the contrast sensitivity (MS) with the help of contrasting optotypes. An increase of the incidence of clinically significant cases of myopia with age in both girls and boys was observed in the study. Its detection rate
(33.74\%; $n=251$ ) in the students, participated in our study, is almost twice as high as the detection rate of hypermetropia (17.20\%; $n=128)$. The general tendencies of the deterioration of contrast sensitivity generally complied with the changes in the condition of the refractory apparatus in the groups of female and male students and were identical. It was revealed that in the group of persons with MS index within the range of $0-2$, there were $73.04 \%$ of the total number of females and $72.00 \%$ of the total number of males with refraction disorders belonging to different age groups.

Conclusions. The similarity of the tendencies in the increase of the frequency of clinically significant cases of contrast sensitivity disorders and refractive-accommodative system suggests that studies with the use of the contrasting optotype table can be used as an early method of preclinical diagnosis of refractive disorders in school-age children.

\section{Keywords: contrast sensitivity, visual analyzer, myopia, hypermetropia, disorders of refraction, prevention of eyesight disorders in children.}

можна попередити. За даними МОЗ України, щороку у дітей в Україні реєструється 840 тисяч випадків вперше виявлених офтальмологічних захворювань.

Нині в Україні реєструється один сліпий на 10000 дитячого населення, що корелюється з загальносвітовими тенденціями [2], на 1000 дітей припадає 4,3 дитини зі сліпотою (одного або обох очей) i 38,0 - зі слабкозорістю [3]. Фактично у нашій державі проживають 10,7 тисяч сліпих і слабкозорих дітей, і щорічно їхня кількість збільшується на тисячу [4].

Результати щорічних профілактичних оглядів українських школярів свідчать, що патологія зору відзначається у 14\% учнів: найчастіше реєструється діагноз міопія, дещо рідше - гіперметропія, астигматизм, косоокість [5]. При цьому відзначається, що частота виявлення учнів зі зниженою гостротою зору за час навчання у школі збільшується у 3-5 разів, і в 11 класі частка учнів з офтальмологічною патологією становить $30 \%[4]$.

При цьому останніми роками спостерігається погіршення зору у дітей та підлітків
(ДП) через збільшення інформаційного навантаження в умовах додаткового психогенного стресу, спричиненого навколишньою стресовою ситуацією. Щорічне збільшення кількості дітей та підлітків 3 погіршенням зору у новій українській школі становить у середньому $5 \%$. Це переважно учні молодших та середніх класів, рідше - старшокласники [6, 7].

Головні негативні фактори впливу на сенсорну систему зумовлені неадекватним напруженням зорової системи через надмірні зорові навантаження під час шкільних занять та підготовки до них, а також через роботу за монітором та використання екранів інших гаджетів. Так, надмірне навантаження, яке не відповідає функціональним віковим можливостям ока у шкільному віці, часто є основою для виникнення патології органів зору - порушень рефракції (міопії), бінокулярності (косоокості) тощо.

У школярів, які тривалий час працюють за моніторами, найчастіше спостерігаються порушення бінокулярного зору та зміни рефракції, що значно погіршує зір дитини і впливає на її навчання та соціалізацію у суспільстві. Зважаючи на наявність в Україні понад 20000 загальноосвітніх навчальних закладів (ЗНЗ), в яких навчаються близько 4,5 мільйонів учнів [8, 9], масштаби цієї проблеми є колосальними. Водночас в Україні донині немає чіткого розуміння поширеності та структури порушень зору серед дітей різних вікових груп.

Зважаючи на вказане вище, вивчення функціональних змін ока та стану зорового аналізатора (ЗА) сучасних школярів можна вважати актуальним медико-біологічним завданням, яке має науково-медичне та практичне значення. Водночас, незважаючи на значну кількість досліджень функціонального стану зорового аналізатора (ЗА) у ДП, даних про зв'язок показників акомодаційновергентної системи ока та стану рефракції і її порушення з якістю та обсягом зорових навантажень в умовах сучасної нової української школи (НУШ) надзвичайно мало. Це перешкоджає створенню об'єктивних уявлень про реальний стан зазначеної проблеми.

Мета дослідження: співвіднести стан рефракційноакомодаційної системи та

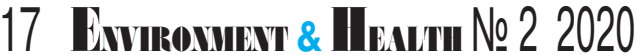


показників контрастної чутливості у школярів різних вікових груп. Об'єкт дослідження - зоровий аналізатор у школярів різних вікових груп. Предмет дослідження - стан контрастної чутливості у школярів різного віку з нормальною та порушеною рефракцією ЗА.

Матеріал і методика досліджень. У роботі використано схему вікової періодизації людини, що враховує анатомічні, фізіологічні, соціальні фактори, прийняту на VII Конференції з проблем вікової морфології, фізіології та біохімії (1965).

Оскільки навантаження на зоровий апарат починає зростати приблизно з 4-х років, то нашим дослідженням було охоплено дітей, які належать до таких вікових груп: перше дитинство (дівчатка та хлопчики віком 4-7 років), друге дитинство (дівчатка віком 8-11 років та хлопчики віком 8-12 років), підлітковий вік (дівчатка віком 12-15 років та хлопчики віком 13-16 років), юнацький вік (дівчата віком 17-20 років та юнаки віком 17-21 рік). Розподіл учнів у досліджуваних вікових групах був таким: дівчатка 6-7 років - група Д хлопчики 6-7 років - група $X_{1}$, дівчатка 8-11 років - група Д, хлопчики 8-12 років - група $\mathrm{X}_{2}$, дівчатка $12-15$ років - група Д хлопчики 13-16 років - група $\mathrm{X}_{3}$, дівчата 16-17 років - група $Д_{4}$, юнаки 17 років - група Ю.

3 у рахуванням якісного

Таблиця 1

Стан рефракційно-акомодаційної системи та показники контрастної чутливості (КЧ) у дітей різних вікових груп

\begin{tabular}{|c|c|c|c|c|}
\hline \multicolumn{2}{|c|}{ Вікова група } & $\leq 2$ & $=2,5$ & $3 \leq$ \\
\hline \multirow{3}{*}{$Д_{1}(n=66)$} & Норма & - & 3 & 25 \\
\hline & Міопія & 4 & 8 & - \\
\hline & Гіперметропія & 18 & 8 & - \\
\hline \multirow{3}{*}{$Д_{2}(n=141)$} & Норма & - & 10 & 70 \\
\hline & Міопія & 26 & 16 & - \\
\hline & Гіперметропія & 14 & 5 & - \\
\hline \multirow{3}{*}{$Д_{3}(n=126)$} & Норма & 1 & 14 & 40 \\
\hline & Міопія & 47 & 7 & - \\
\hline & Гіперметропія & 11 & 5 & - \\
\hline \multirow{3}{*}{$Д_{4}(n=60)$} & Норма & 1 & 7 & 17 \\
\hline & Міопія & 26 & 3 & - \\
\hline & Гіперметропія & 3 & 3 & - \\
\hline \multirow{3}{*}{$X_{1}(n=51)$} & Норма & - & 3 & 23 \\
\hline & Міопія & 8 & 6 & - \\
\hline & Гіперметропія & 8 & 3 & - \\
\hline \multirow{3}{*}{$X_{2}(n=155)$} & Норма & - & 14 & 84 \\
\hline & Міопія & 21 & 13 & - \\
\hline & Гіперметропія & 16 & 6 & 1 \\
\hline \multirow{3}{*}{$X_{3}(n=91)$} & Норма & - & 17 & 25 \\
\hline & Міопія & 25 & 5 & - \\
\hline & Гіперметропія & 12 & 7 & - \\
\hline \multirow{3}{*}{$Ю(n=54)$} & Норма & - & 1 & 9 \\
\hline & Міопія & 30 & 6 & - \\
\hline & Гіперметропія & 6 & 2 & - \\
\hline
\end{tabular}

Примітка до таблиць 1 і 2: У дужках зазначено загальну кількість досліджуваних осіб вікової групи, в яких визначали показники контрастної чутливості та гостроти зору. характеру показників, що досліджувалися, для статистичного аналізу даних було використано непараметричний метод 2-тест.

Дослідження проведено за участі 744 школярів, 3 яких 393 особи жіночої статі та 351 особа чоловічої. Учасники дослідження розподілилися за віковими групами таким чином: група Д $1-66$ дівчаток, група Д 2 - 141 дівчинка, група $Д_{3}-126$ дівчаток, група Д 60 дівчат, група $X_{1}-51$ хлопчик, група $\mathrm{X}_{2}-155$ хлопчиків, група $X_{3}-91$ хлопчик, група Ю - 54 юнаки. У кожного з обстежуваних визначали гостроту зору з використанням таблиць Головіна-Сивцева, контрастну чутливість (КЧ) - 3 використанням таблиці контрастних оптотипів [5, 6]. Вказані показники визначалися для кожного ока окремо. Через відсутність істотної різниці між вибірками даних, що отримані при дослідженні правого та лівого ока, числові характеристики представлено виключно за результатами досліджень правого ока.

Значення показника КЧ $\leq 2$ вважали таким, що свідчив про наявність патологічних змін, значення показника КЧ =2,5 вважали межею між патологією та нормою, значення показника КЧ $\geq 3$ вважали такими, що відповідають нормі.

Проведені дослідження цілком відповідають законодавству України про охорону здоров'я, принципам Гельсінської декларації Всесвітньої медичної асоціації (2013) та Конвенції Союзу Європи щодо прав людини і біомедицини. Батьки або родичі кожного учня підписували інформовану згоду на участь у дослідженні. Виконавцями дослідження вжито необхідні заходи для забезпечення анонімності пацієнтів.

Результати дослідження. Кількісне порівняння наповненості кожної з вікових груп осіб жіночої та чоловічої статей не виявило статистично значущих розбіжностей між ними $\left(\chi^{2}=6,195 ; p=0,103\right)$. 
КОНТРАСТНАЯ ЧУВСТВИТЕЛЬНОСТЬ КАК МЕТОД РАННЕГО ВЫЯВЛЕНИЯ НАРУШЕНИЙ РЕФРАКЦИИ У ДЕТЕЙ РАЗНОГО ВОЗРАСТА

${ }^{1}$ Харченко Л.Б., 1 Плиска А.И., 2 Груша М.М.,

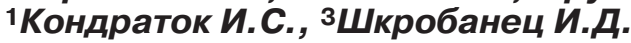

1 Национальный педагогический университет им. Н.П. Драгоманова, г. Киев, Украина

2 Национальный медицинский университет им. А.А. Богомольца, г. Киев, Украина

знациональная академия медицинских наук Украины, г. Киев

\section{Цель исследования: соотнести состояние рефракционно-аккомодационной системы и показателей контрастной чувствительности у школьников разных возрастных групп. В работе использована схема возрастной периодизации человека, учитывающей анато- мические, физиологические и социальные факторы. \\ Результаты. У каждого из обследуемых определяли остроту зрения с помощью таб- лиц Головина-Сивцева, контрастную чувстви- тельность (КЧ) - с помощью таблицы конт- растных оптотипив. В результате проведен- ных исследований было установлено, что с возрастом наблюдается нарастание частоты клинически значимых случаев миопии и у девочек, и у мальчиков. Частота ее обнаруже-}

ния (33,74\%; $n=251)$ у школьников, участвовавших в исследовании, почти вдвое превышает частоту выявления гиперметропии (17,20\%; n=128). Общие тенденции ухудшения состояния контрастной чувствительности в целом соответствовали изменениям в состоянии рефрактерного аппарата во всех группах учащихся и имели тождественный характер. Выявлено, что в группу учащихся с индексом КВ в пределах 0-2 попадает 73,04\% от общего количества девочек и 72,00\% мальчиков, принадлежащих к разным возрастным группам, у которых выявлены нарушения рефракции.

Выводы. Обнаруженное сходство тенденций в увеличении частоты клинически значимых случаев нарушений состояния контрастной чувствительности и рефракционно-аккомодационной системы позволяют предположить, что исследования с использованием таблицы контрастных оптотипов можно использовать в качестве раннего метода доклинической диагностики нарушений рефракции у школьников.

Ключевые слова: контрастная чувствительность, зрительный анализатор, миопия, гиперметропия, нарушения рефракции, профилактика нарушений зрения у детей.
У кожній з зазначених вікових груп нами було проведено дослідження стану рефракції та контрастної чутливості (табл. 1).

Загалом у зазначених групах учнів порушення рефракції було виявлено у 51,08\% осіб $(n=380)$. При цьому міопія була наявною у 33,74\% $(\mathrm{n}=251)$, а гіперметропія - y $17,20 \%(n=128)$.

Порушення рефракції у групі дівчаток було виявлено у $51,91 \%(n=204)$, серед яких міопія - у $34,86 \%(n=137)$, гіперметропія - у 17,05\% (n=67). Порушення рефракції у групі хлопчиків і юнаків було виявлено у 49,86\% ( $n=175)$, серед яких міопія - у $32,48 \%$ $(\mathrm{n}=114)$, гіперметропія - y $17,38 \%(n=61)$.

Визначення стану рефракції у дівчаток різних вікових груп виявило порушення у групі Д - 57,58\% (n=38), з яких на міопію припадало $18,18 \%$ $(\mathrm{n}=12)$, а на гіперметропію $39,40 \% \quad(n=26)$. У групі Д2 порушення рефракції виявлено у $43,26 \%(n=61)$, з яких на міопію припадало 29,79\% $(n=42)$, на гіперметропію $13,48 \% \quad(n=19) ;$ у групі Д порушення рефракції виявлено у $56,35 \%(n=71)$, з яких на міопію припадало 42,86\% $(n=54)$, на гіперметропію $12,70 \% \quad(n=16)$. У групі Д порушення рефракції виявлено у $58,33 \%(n=35)$, з яких на міопію припадало 48,33\% $(n=29)$, на гіперметропію $10,00 \% \quad(n=6)$. Порівняння вікових груп Д $, ~ Д_{2}, Д_{3}$ та Д 4 за відсотковим внеском дівчаток з порушеннями рефракції через міопію та гіперметропію свідчить про статистично значуще $\left(\chi^{2}=38,884 ; p<0,01\right)$ збільшення частоти виявлення міопії при переході від молодшої до старшої вікової групи на тлі збереження достатньо сталих значень частоти виявлення у цих групах гіперметропії.

Визначення стану рефракції у хлопчиків і юнаків виявило її порушення у групі $X_{1}$ у 49,02\% $(n=25)$, я яких на міопію припадало 27,45\% $(n=14)$, на гіперметропію - 21,57\% (n=11). У групі $\mathrm{X}_{2}$ порушення рефракції виявлено у 36,77\% (n=57), 3 яких на міопію припадало $21,94 \% \quad(n=34)$, на гіперметропію - 14,84\% (n=23). У групі $\mathrm{X}_{3}$ порушення рефракції виявлено у 53,85\% (n=49), 3 яких на міопію припадало $32,97 \%(n=30)$, на гіперметропію - 20,88\% (n=19).

Серед юнаків групи Ю порушення рефракції виявлено у $81,48 \%(n=44)$, я яких на міопію припадало 66,67\% (n=36), на гіперметропію - 14,81\% $(n=8)$. Порівняння вікових груп $\mathrm{X}_{1}, \mathrm{X}_{2}, \mathrm{X}_{3}$ та Ю за відсотковим внеском учнів з порушеннями рефракції через міопію та гіперметропію свідчить про статистично значу-

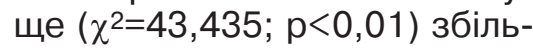
шення частоти виявлення міопії при переході від молодшої до старшої вікової групи на тлі збереження досить сталих значень частоти виявлення гіперметропії. Таким чином, загальні тенденції щодо погіршення стану рефрактерного апарату у групах учнів жіночої та чоловічої статі не мають принципових розбіжностей.

Порівняння частоти міопії та гіперметропії в учнів обох статей у межах кожної вікової групи окремо виявило відсутність статистично значущих розбіжностей між Д 1 та $\mathrm{X}_{1}$ групами $\left(\chi^{2}=4,459 ; p=0,108\right), Д_{2}$

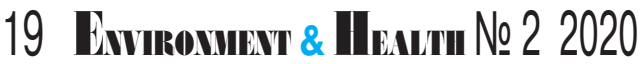




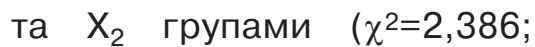
$\mathrm{p}=0,304)$ та $Д_{3}$ i $X_{3}$ групами $\left(\chi^{2}=3,594 ; p=0,166\right)$. Порівняння частоти міопії та гіперметропії в учнів груп Д виявило наявність статистично значущих розбіжностей $\left(\chi^{2}=7,172 ; p=0,028\right)$, які, ймовірно, зумовлені більшою прогресивністю збільшення міопії у групі юнаків порівняно з дівчатами четвертої вікової групи.

Нами також було визначено стан КЧ в учнів усіх груп (табл.2). Згідно з зазначеними у методиці критеріями оцінки стану КЧ у кожній групі оцінювали представництво учнів 3 нормальною КЧ, 3 такою, яка межує з нормальною КЧ, та порушеною КЧ. Окремо, у межах кожної віко-

\section{Стан рефракційно-акомодаційної системи за умови низьких значень контрастної чутливості (КЧ) у школярів різних вікових груп}

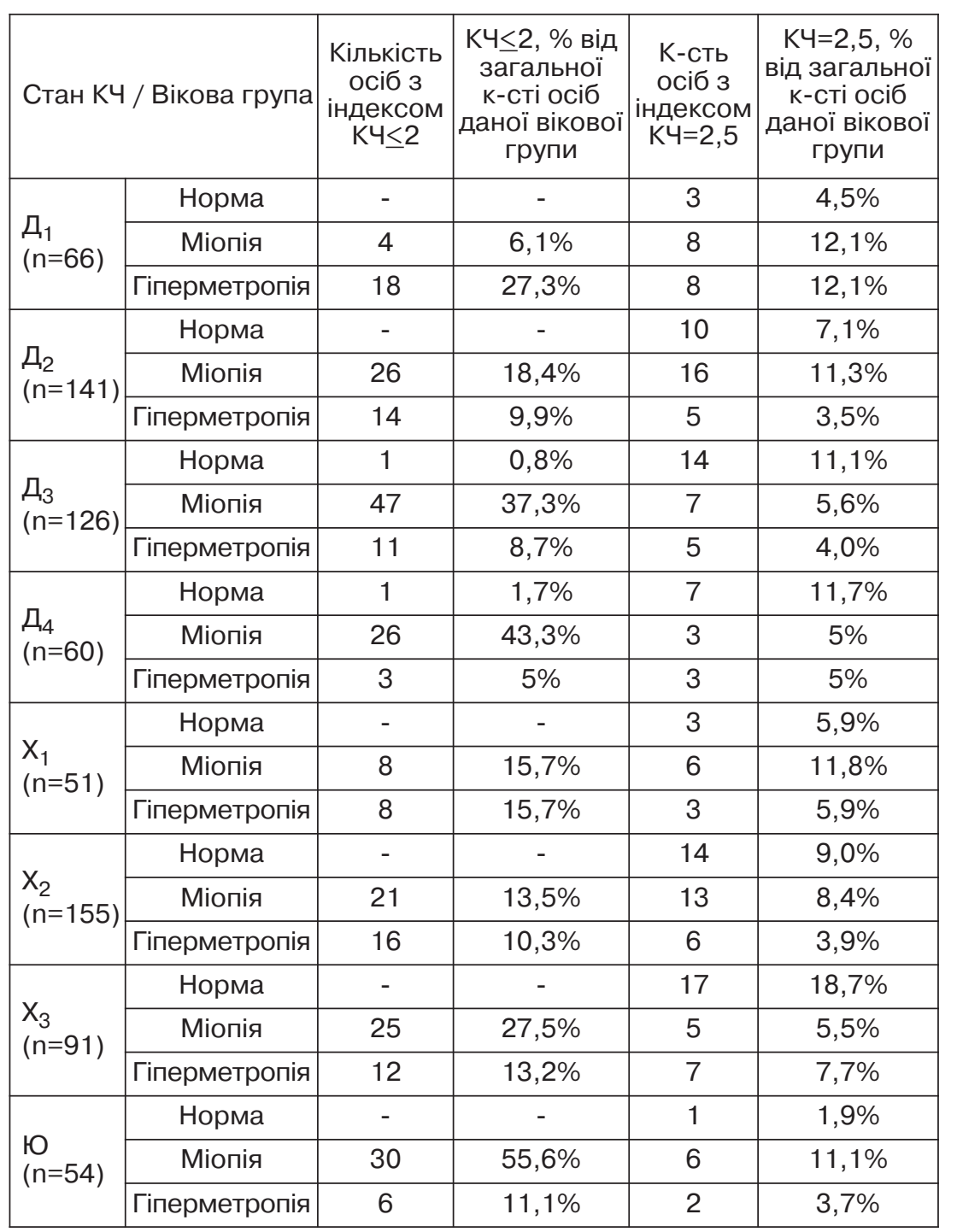

$(n=90)$. До того ж, серед дівчаток знижений рівень КЧ $(\leq 2)$, за умови наявності у дітей порушень рефракції, що зумовлені міопією або гіперметропією, спостерігався у $37,91 \%(n=149)$. Це відповідає 73,04\% від загальної кількості дівчаток із різних вікових груп, в яких виявлено порушення рефракції $(n=204)$. Відсоток учнів різних вікових груп з виявленими порушеннями КЧ був таким: серед дівчаток групи Д 1 - 33,33\% $(n=22), Д_{2}-28,37 \%(n=40), Д_{3}$ $-46,83 \%(n=59), Д_{4}-50,00 \%$ $(n=30)$. Подібна тенденція спостерігалася і під час окремого аналізу відсотка дівчаток з порушенням КЧ $(\leq 2)$ на тлі міопії різного ступеня.

Межові значення цього показника було виявлено серед дівчаток групи Д у $28,37 \%$ ( $n=19)$, у групі Д - у $21,99 \%$ $(n=31)$, у групі Д - у $21,43 \%$ ( $n=27)$, у групі $Д_{4}-$ у $21,67 \%$ $(n=13)$.

Визначення стану КЧ у хлопчиків і юнаків виявило ії порушення $(\mathrm{K} 4 \leq 2) \quad$ у $35,90 \%$ $(n=126)$, а іï межові значення $(K 4=2,5)-y \quad 23,65 \% \quad(n=83)$. Знижений рівень КЧ $(\leq 2)$, за наявності порушень рефракції, що зумовлені міопією або гіперметропією, спостерігається у $35,88 \%(n=126)$. Це становить 72,00\% від загальної кількості учнів із різних вікових груп 3 порушенням рефракції $(n=175)$. Відсоток учнів з виявленими порушеннями КЧ був таким: серед хлопчиків групи $\mathrm{X}_{1}-31,37 \%$ $(n=16)$, групи $X_{2}-23,87 \%$ $(n=37)$, групи $x_{3}-40,66 \%$ $(n=37)$, серед юнаків групи Ю - 66,67\% (n=36). Подібна тенденція спостерігалася і під час окремого аналізу відсотка учнів з порушенням КЧ $(\leq 2)$ на тлі міопії різного ступеня.

Межові значення цього показника було виявлено серед хлопчиків групи $\mathrm{X}_{1}$ у $23,53 \%$ $(n=12)$, групи $X_{2}-y 21,29 \%$ $(n=33)$, групи $x_{3}-y 31,87 \%$ ( $n=29)$, серед юнаків групи Ю - у $16,67 \%(n=9)$.

Порівняння вікових груп Д $Д_{2}, Д_{3}$ та $Д_{4}$ за відсотковим 
внеском дівчаток з порушенням КЧ вказує на наявність статистично значущого $\left(\chi^{2=}\right.$ 17,394; $p<0,01)$ збільшення учениць під час переходу від молодшої до старшої вікової групи на тлі збереження відносно сталої кількості їх 3 межовим значенням показника КЧ у кожній віковій групі. Порівняння вікових груп $\mathrm{X}_{1}$, $\mathrm{X}_{2}, \mathrm{X}_{3}$ та Ю за відсотковим внеском учнів з порушенням КЧ вказує на наявність статистично значущого ( $\chi^{2}=44,974$; $\mathrm{p}<0,01)$ збільшення їх при переході від молодшої до старшої вікової групи на тлі відсутності закономірних змін у кількості учнів з межовим значенням показника КЧ у кожній віковій групі.

Також було проаналізовано наповнення різних вікових груп дівчаток (групи Д $, ~ Д_{2}, Д_{3}$ та Д 4 разом) з порушенням КЧ (<2) за наявності у них порушень рефракції, що зумовлені міопією або гіперметропією, порівняно з наповненням відповідних вікових груп хлопчиків і юнаків (групи $\mathrm{X}_{1}, \mathrm{X}_{2}, \mathrm{X}_{3}$ та Ю разом). Статистичний аналіз даних зазначених груп вказує на відсутність статистично вірогідних відмінностей між вибірками $\left(\chi^{2}=4,569 ; \quad p=\right.$ 0,207).

Під час аналізу наповнення різних вікових груп дівчаток 3 порушенням КЧ ( $\leq 2)$ за наявності у них порушень рефракції, що зумовлені виключно міопією, порівняно з наповненням відповідних вікових груп хлопчиків і юнаків також виявлено відсутність статистично вірогідних відмінностей між вибірками $\left(\chi^{2}=7,015 ; p=0,072\right)$.

Порівняння стану КЧ в учнів жіночої та чоловічої статі у межах кожної вікової групи окремо виявило відсутність статистично значущих розбіжностей між групами Д 1 та $X_{1}\left(\chi^{2}=0,700 ; p=0,705\right), Д_{2}$ та $\mathrm{X}_{2}\left(\chi^{2}=0,971 ; \mathrm{p}=0,616\right)$, Д $_{3}$ i $\mathrm{X}_{3}$ $\left(\chi^{2}=3,008 ; p=0,223\right), Д_{4}$ і Ю $\left(\chi^{2}=3,428 ; \quad p=0,181\right)$. Отже, загальні тенденції щодо погіршення стану КЧ так само, як і зміни у стані рефракції зорової системи, в усіх групах учнів мають тотожній характер.

Крім зазначеного вище, привертає увагу відсутність чітких тенденцій у групі учнів 3 індексом КЧ=2,5. Це може бути зумовленим наявністю серед учнів зі значенням індексу КЧ=2,5 осіб без ознак порушень рефракції.

Аналіз і обговорення отриманих результатів. Втрата зору, навіть часткова, створює проблеми взаємодії людини 3 середовищем і суспільством, перешкоджає здійсненню трудової діяльності та набуванню знань і навичок, затримує розвиток особистості [10]. При цьому зорові розлади можуть бути спричинені не лише умовами зорової роботи, але й іншими соціальними і побутовими впливами, такими як харчування, зокрема вітамінна недостатність, загальна освітленість приміщень, зміна характеру дозвілля, зміна циркадних ритмів тощо. Встановлено безпосередній зв'язок між станом здоров'я людини і порушеннями зору, зумовленими спадковою схильністю та характером росту і розвитком самого органу зору.

Саме у шкільному віці особливого значення набуває гігієна зору у дітей, завданням якої є забезпечення умов оптимального функціонування периферійного відділу зорового аналізатора. Проте, незважаючи на намагання дотримуватися гігієнічних норм і стандартів освітньої діяльності, саме у шкільному віці у значної частки дітей з'являються зорові розлади. Провідне місце серед порушень у зоровій системі школярів належить міопії (короткозорості).

За результатами нашого дослідження, міопії дійсно належить провідне місце за частотою виникнення порушень рефракції. Частота її виявлення $(33,74 \% ; n=251)$ у школярів, що брали участь у нашому дослідженні, майже вдвічі перевищує частоту виявлення гіперметропії $(17,20 \%, n=128)$. Нами також отримано дані щодо статистично значущого наростання відсотка порушень рефракції у старших вікових групах (переважно за рахунок кількості випадків діагностики міопії) і у дівчаток, і у хлопчиків та юнаків. Останнє кореспондується зі збільшенням ступеня навантажень на ЗА у процесі шкільних занять. Адже саме у школі діти вперше починають щоденно виконувати досить тривалу навчальну роботу, обсяг якої 3 роками збільшується, що і пояснює отримані нами результати. Проведене нами дослідження КЧ також виявило статистично значуще залежне від віку прогресивне погіршення стану зорової системи.

Роль ранньої діагностики порушень рефракції, передусім короткозорості, є важливою для формування серед школярів «групи ризику» 3 відхиленнями загального стану здоров'я. Відомо, що у дітей $з$ діагностованою короткозорістю частіше, ніж у здорових, зустрічаються зміни опорно-рухового апарату: порушення постави, сколіоз, плоскостопість [11]. Водночас у дітей з міопією, за відсутності належної корекції постави, характеру харчування та режиму навчання і відпочинку, прогресуватимуть погіршення загального стану здоров'я та короткозорість [12]. Бінокулярна система ока повністю формується до 8-12 років. За несвоєчасної діагностики порушення бінокулярного зору до зазначеного віку майже неможливе

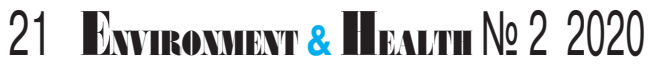


дасть змогу запобігти її прогресуванню серед дитячого населення, $€$ ускладненим виключно кадровою політикою .

Привертає увагу факт узгодження результатів оцінки стану рефракції зорової системи та значень індексу КЧ в учнів, яких ми обстежували. Нами виявлено, що до групи школярів 3 індексом КЧ у межах 0-2 потрапляють 73,04\% від загальної кількості дівчаток та 72,00\% хлопчиків і юнаків із різних вікових груп з виявленим порушенням рефракції.

Цей факт свідчить про потенційну можливість використання методу визначення стану КЧ з використанням таблиці контрастних оптотипів для ранньої доклінічної діагностики порушень рефракції у дітей шкільного віку.

\section{Висновки}

Для школярів характерним $€$ статистично значуще збільшення частоти клінічних значущих випадків погіршення стану рефракційно-акомодаційної системи при переході від молодшої до старшої вікової групи. Подібну тенденцію виявлено у вікових групах учнів під час аналізу стану контрастної чутливості зору з використанням таблиці контрастних оптотипів. Таким чином, однонаправленість змін у стані рефракційно-акомодаційної системи та стані контрастної чутливості зору дають змогу припустити, що дослідження 3 використанням таблиці контрастних оптотипів можна використовувати як ранній метод доклінічної діагностики порушень рефракції у дітей шкільного віку.

\section{ЛІТЕРАТУРА}

1. Риков С.О., Савіна О.М. Проблеми спадкової патології очей у дітей і роль офтальмологів у її вирішенні.

Таврический медико-биологический вестник. 2015.

T. 15, № 4 (60). C. 328-331.

2. Баринов Ю.В. В центре борьбы со слепотой спасают зрение детям со всей Украины: [беседа с заведую- щим Центра детской офтальмологии]. URL :

https://www. unian.net/health/ country/571665-v-tsentre-

borbyi-so-slepotoy-spasayutzrenie-detyam-so-vseyukrainyi.html

3. Бистрова Ю.О., Петруня А.М., Коваленко В.Є. та ін. Комплексний супровід дітей з порушеннями зору в умовах навчального закладу : навч.-метод. посіб. Луганськ : вид-во ДЗ «ЛНУ ім. Тараса Шевченка», 2012. 288 с.

4. Костецька А.О. Медикоорганізаційна технологія оптимізації моніторингу порушень зору у школярів : автореф. дис. ... канд. мед. наук : 14.02.03 - соціальна медицина. Національна медична академія післядипломної освіти імені П.Л. Шупика.

Київ, 2014. 26 с.

5. Петрюк С.Є. Вплив патологічних станів дітей на навчально-виховний процес у загальноосвітніх навчальних закладах. Вісник Глухівського національного педагогічного університету імені Олександра Довженка. Серія: Педагогічні науки. 2015. Вип. 27.

C. 207-214

6. Yang H.K., Choi J.Y., Kim D.H. and Hwang J.-M. Changes in refractive error related to spectacle correction for hyperopia. PLOS ONE. 2014. Vol. 9 (11). e110663

7. Mosley M.J., Wallace M.P., Stephens D.A., Fielder A.R., Smith L.C. et al. Personalized versus standardized dosing strategies for the treatment of childhood amblyopia: study protocol for a randomized controlled trial. Trials. 2015. Vol. 16. 189.

8. Mourits D.L., Hartong D.T., van Beek J.H.M., Witte B.I., Tan H.S., Moll A.C. A novel method to measure artificial eye motility. Ophthalmic Plastic \& Reconstructive Surgery. 2017. Vol. 33. Issue 6.

P. 413-418.

9. Holden B.A., Fricke T.R., Wilson D.A. et al. Global Prevalence of Myopia and High Myopia and Temporal Trends 
from 2000 through 2050. Ophtalmol. 2016. Vol. 123 (5). 103601042.

10. Бейтс У.Г., Корбет М.Д. Улучшение зрения без очков по методу Бейтса.

Руководство к быстрому

улучшению зрения. Вильнюс

: Полина, 1995. 272 с.

11. Давыденко Э.В.

Как улучшить зрение.

Нетрадиционные методы лечения. Профилактика и лечение нарушений зрения по методу американского доктора У.Г. Гейтса.

Практические советы.

Упражнение. Киев : Орбита, 1991. 79 с.

12. Смерека Л.Г. Анализ изменений анатомо-оптической структуры миопических глаз и организация профилактики миопии в школах : автореф. дисс. ... канд. мед. наук : спец. 14.00.08.

Харьков, 1994. 12 с.

13. Ферфильфайн И.Л. Близорукость. К. : Книга плюс, 1987. С. 9-17.

14. Моісеєнко P.O., Голубчиков М.В., Михальчук В.М., Риков С.О. та ін. Офтальмологічна допомога в Україні за 2014-2017 роки : аналітично-статистичний довідник. Кропивницький : ПОЛІУМ, 2018. С. 4-5.

\section{REFERENCES}

1.Rykov S.O. and

Savina O. M.

Tavricheskiymediko-biologicheskiyvestnik.2015; 15 (4) : 328-331 (in Ukrainian).

2. Barinov Yu.V. V tsentre borby so slepotoy spasayut zreniye detyam so vsey Ukrainy [At the Center for the Fight Against Blindness, the Children from all over Ukraine Are Being Saved their Eyesight]. URL :https://www.unian.net/health/ country/571665-v-tsentreborbyi-so-slepotoy-spasayutzrenie-detyam-so-vseyukrainyi.html (in Russian).

3. Bystrova Yu.O.,

Petrunia A.M., Kovalenko V.Ye. et al. Kompleksnyi suprovid ditei z porushenniamy zoru $v$ umovakh navchalnoho zakladu : navchalno-metod. Posibnyk [Comprehensive Support for Children with Eyesight
Impairments at the Educational Institution: Educ. and Method.

Manual]. Luhansk ; 2012 :

288 p. (in Ukrainian).

4. Kostetska A.O. Medyko-

orhanizatsiina tekhnolohiia

optymizatsii monitorynhu

porushen zoru u shkoliariv :

avtoref. dys. ... kand. med.

nauk: sotsialna medytsyna

[Medical-Organizational

Technology of Optimization of

Monitoring of Visual

Impairments in Schoolchildren:

Author. Diss. ... Cand. Medical

Sciences : Social Medicine].

Kyiv ; 2014 : 26 p.

(in Ukrainian).

5. Petriuk S.Ye. Vplyv patolo-

hichnykh staniv ditei na navchalno-vykhovnyi protses $u$ zahalnoosvitnikh navchalnykh zakladakh [Influence of the Pathological States of the Children on the Training-

Educational Process at

Secondary Schools]. In :

Visnyk Hlukhivskoho natsionalnoho pedahohichnoho universytetu imeni Oleksandra

Dovzhenka. Seriia:

Pedahohichni nauky [Bulletin of Hlukhiv National Olexander

Dovzhenko Pedagogical

University. Series: Pedagogical

Sciences]. 2015 ; 27 : 207-214

(in Ukrainian).

6. Yang H.K., Choi J.Y.,

Kim D.H. and Hwang J.-M.

PLOS ONE. 2014 ; 9 (11) :

e110663.

7. Mosley M.J., Wallace M.P., Stephens D.A., Fielder A.R., Smith L.C. et al. Trials. 2015 ; 16. 189.

8. Mourits D.L., Hartong D.T., van Beek J.H.M., Witte B.I.,

Tan H.S. and Moll A.C.

Ophthalmic Plastic \&

Reconstructive Surgery. 2017 ; 33 (6) : 413-418.

9. Holden B.A., Fricke T.R., Wilson D.A. et al.

Ophtalmology. 2016 ; 123 (5) : 103601042.

10. Bates W.H. and

Korbett M.D. Uluchsheniye zreniya bez ochkov po metodu Beytsa. Rukovodstvo k bystromu uluchsheniyu zreniya [Improvement of Eyesight without Glasses According to the Bates Method.

A Guide to Rapid Eyesight
Improvement]. Vilnius :

Polina ; 1995 : 272 p.

(in Russian).

11. Davydenko E.V. Kak uluchshit zreniye.

Netraditsionnye metody lecheniya. Profilaktika i lecheniye narusheniy zreniya po metodu amerikanskogo doktora U.G. Geytsa.

Prakticheskiye sovety. Uprazhneniye [How to Improve Eyesight. Alternative Treatment Methods. Prevention and Treatment of Eyesight Impairment According to the Method of the American Doctor U.G. Gates. Practical Advice. Exercise].

Kiev : Orbita ; 1991 ; 79 p. (in Russian).

12. Smereka L.G. Analiz izmeneniy anatomo-opticheskoy struktury miopicheskikh glaz i organizatsiya profilaktiki miopii v shkolakh : avtoref. diss. ... kand. med. nauk [Analysis of Changes in Anatomical and Optical Structure of Myopic Eyes and Organization of Myopia Prevention at Schools: Abstract. Diss. Cand. Med. Sciences]. Kharkov ; 1994 : 12 p. (in Russian).

13. Ferfilfain I.L. Blizorukost [Myopia]. Kiev : Kniga plus ; 1987 : 9-17 (in Russian).

14. Moiseienko R.O., Holubchykov M.V., Mykhalchuk V.M., Rykov S.O. et al. Oftalmolohichna dopomoha v Ukraini za 2014-2017 roky : analitychno-statystychnyi dovidnyk [Ophthalmic Care in Ukraine over 2014-2017: Analytical and Statistical Reference Book].

Kropyvnytskyi : POLIUM ; 2018 : 4-5 (in Ukrainian).

Надійшла до редакції 21.02.2020 